\title{
Blending Artistic, Research and Teaching Practices in the Context of Teacher Education. An a/r/tographical Approach of an Arts-Based Educational Project
}

\author{
Maria Kampouropoulou (Corresponding author) \\ Department of Primary Education, University of the Aegean \\ Dimokratias 1, 85100, Rhodes, Greece \\ Tel: 30-22410-99229 E-mail: kampour@rhodes.aegean.gr
}

Received: February 20, 2015 Accepted: February 27, 2015 Published: March 30, 2015

doi:10.5296/jet.v2i2.7351 URL: http://dx.doi.org/10.5296/jet.v2i2.7351

\begin{abstract}
The purpose of this article is to explore an art education project within the theoretical and methodological context of a/r/tography. An arts-based educational project carried out by the Primary Education Department of University of Aegean, is examined through an artistic and inquiry process where the roles of artists, researchers and teachers are deeply interrelated. In order to explore how artful research and the co-creative process can help teachers access and reframe understandings of teaching and learning, the teacher trainees were interviewed and expressed ideas and beliefs on education, art, inquiry, teaching and knowledge construction. Findings of the research support the potential of art-based educational projects to evoke strong senses of artist/researcher/teacher self in relation to the community, empower cognitive, communicative and artistic skills, promote holistic learning and thus to play a significant role in the field of teacher education.
\end{abstract}

Keywords: a/r/tography, art education, teacher education, holistic learning

\section{Introduction: Arts and Education}

Ever since John Dewey (1934) argued that the source of aesthetic experience is every day, commonplace experience, it is broadly accepted that art, because of its potential to provide students with an aesthetic experience, can play a catalytic role in the learning process (Kampouropoulou et al., 2011). Especially nowadays, in the era of contemporary education, the possibilities of encouraging such experiences have been seriously, considered (Wong et al. 2001; Hadzigeorgiou, 2005) and the demand of new teaching methods, facing the challenge of multidimensional social reality, meeting the needs of our time and dealing with the complex nature of the problems that arise (Kampouropoulou et al., 2011), illuminate the importance of teaching and learning in, about, and through the arts (Gradle, 2005; Gruenewald, 2003; Ulbricht, 1998; Armstrong, 2000). 
In the above context, education policies around the world, recognize the role of arts into learning environments and embrace a variety of approaches concerning:

- Arts Education, the term referring to 'a comprehensive and sequential education in separate and distinct artistic disciplines, such as: dance, music, drama, folk arts, media arts and visual arts' (Eisner et al., 2004), provided by schools, cultural organizations and other community-based providers, all influenced by an array of arts education policies and practices (Gude, 2009; Eisner et al., 2004; Macdonald, 2004; Efland, 1990).

- Arts in education, the term referring to the instrumental use of artistic skills and experiences as educational tools that promote learning in non-artistic disciplines (Catterall \& Deasy, 2002). Learning through art experiences has gained broad acceptance as an interdisciplinary tool that promotes scientific literacy (Kambouropoulou et al., 2011; Skoumios, \& Savvaidou-Kambouropoulou, 2012, Carmena, 2011; Labriole, 2010), scientific innovation (Root-Bernstein et al., 2008), academic achievement (Catterall \& Deasy, 2002), managing skills (Austin \& Devin, 2003), development of innovative leadership (Seifter \& Buswick, 2005; Adler, 2004).

Revelantly to the above trends, arts - based forms of educational research has been developed since 1970s, in order to study the use of arts-based learning on a wide range of informal learning environments (Eisner, 1976; Greene, 1975; Grumet, 1978). By the 1990s this new 'stream of practice' (Sinner et al., 2006) - an art form used to describe the outlook of the researchers, who in turn communicate their engagement with the arts(Knowles \& Cole, 2008), was broadly accepted as 'a primary way of understanding and examining experience by both researchers and people involved in their studies' (Knowles \& Cole, 2008).

According to Sinner et al. (2006: 1226) the methodological use of the artistic process 'draws from the creative arts to inform and shape social science research in interdisciplinary ways, thus redefining methodological vehicles in the field of education'.

Among such methodological vehicles, a/r/tography emerged from the ideas, art practices and lived experiences of educators, artists, and researchers developed in the context of arts-based educational research (Irwin, 2004; Irwin \& de Cosson, 2004).

\section{A/r/tography as Method of Arts-Based Research}

$\mathrm{A} / \mathrm{r} /$ tography is an hybrid form of research that spaces between a(artist) and $\mathrm{r}$ (researcher) and t(teacher) (Beare, 2009; Irwin \& de Cosson, 2004; Irwin \& Springgay, 2008; de Cosson, 2003; Irwin, 2003, 2004; Springgay, 2001; Wilson et al., 2002; Springgay et al., 2004; Springgay et al., 2008; Leggo,2008; Norman, 2008; Suominen-Guyas, 2008)

$\mathrm{A} / \mathrm{r} / \mathrm{t}$ is used as an acronym for artist-researcher-teacher. Through the in-between spaces of art-making/ researching/ teaching $(\mathrm{a} / \mathrm{r} / \mathrm{t})$ (Beare, 2009) these three identities exist contiguously. As Springgay, Irwin and Kind (2008) state, 'a/r/tographers don't simply research phenomena in the arts using qualitative means; they are artists-and teachers-and-researchers who examine educational phenomena through an artistic understanding and inquiry process'.

Rita Irwin (2004) one of the founders of a/r/tography, explains that the method is based on 
Aristotle's three realms of knowledge: theory (knowing), praxis (doing) and poesies (making). She describes the theoretical and practical aspects of a/r/tography as dialectical, being 'in equal relationship to one another' (Irwin, 2004). A/r/tography transforms abstract systems of theory and practice (as well as their traditional relationship) to spaces of exchange, reflexivity and relationality found in a continuous state of movement (Irwin 2013). Thus, theorizing and practicing 'become something other than what they were and exist in constant movement toward becoming' (Irwin \& Springgay, 2008), in the luminal in-between (Irwin, 2004). For that reason $\mathrm{a} / \mathrm{r} /$ tography is metaphorically refer to as a 'rhizome' (Deleuze \& Guattari, 1987), -an assemblage of objects, ideas, and structures that move in dynamic motion performing waves of intensities that create new understandings (O'Sullivan 2006; Triggs, et al., 2011).

$\mathrm{A} / \mathrm{r} /$ tography is 'a research methodology, a creative practice and a per formative pedagogy' (Irwin, 2013) growing in all directions, allowing for multiple, entry and exit points, with one point connecting to any other point with lack of beginnings or middles (Irwin, 2013). In this contex, $\mathrm{t}$ a/r/tographers embody the multiple roles of artist, researcher and teacher, 'engaged with the difficulties [and gifts] that each practice and role brings to a particular context' (Springgay et al., 2005) the same time they combine:

The creative freedom and risk-taking of the artist with the theory, rigor and responsibility of the academic researcher, along with the ethics and compassion of the educator (Bickel, 2008).

Though theorists (Irwin, 2004; Springgay, 2008; Bickel, 2008 ) have demonstrated how artful research can help teachers access and reframe understandings of teaching and learning, in the education research literature only few studies exist that use either $\mathrm{a} / \mathrm{r} / \mathrm{t} /$ ograpy or related forms of art-based educational research in teacher education.

It must be noticed that so far, there are no strict theoretical spaces through which to explore artistic ways of knowing and being research. Away from arts-based methodologies that focus on the end result, a/r/tographical works include 'any traditional qualitative data forms, as well as visual, musical, and/or textual works of art' Pourchier, 2010), always raising new questions about 'what is seen and known and what is not seen and known' (Irwin \& Springgay, 2008)

\section{The Study}

The purpose of this paper is to examine the engagement of teacher trainees in an arts-based educational project as a process that promotes holistic learning and knowledge creation in teacher education.

The project, titled 'Scarecrow in the land of Asklepio', was conducted by the Departments of Education of the University of the Aegean, under the central research hypothesis that education on local cultural identity is a driving force for artistic expression, while supporting the development of sustainable attitudes and encouraging active participation. The participants were: 
- 4 members of the academic staff,

- 15 university students (teacher trainees)

- 3 schoolteachers and 50 pupils (the school team) in cooperation with the society's team consisting of:

- the Cultural Organization of Municipality of Southern Rhodes,

- the Cultural Association of the village of Asklepio,

- the cultural societies of villages of the same municipality

- 10 individual members of the local community that volunteered to participate.

Being part of the University team, the teacher trainees had an active role throughout the program, as educators, artists and researchers. For the purpose of the study, the practices of teacher trainees as artists and educators were considered to be forms of research. For that reason, 5 teacher trainees, 3 female and 2 male, ranged from 20-23 years old, representing years 3-4, were interviewed at various stages of the project about their involvement with it.

As 'conversations with purpose' (Merriam, 1998), interviews were informal, having the form of discussions, mostly in groups, in order to create a non-threatening platform for the participants to 'bounce ideas off' with each other and to learn from each others' perspectives and insights. Leggo (2008) describes the value of such studies stating that by entering into the lived experiences of others, all contribute to the constitution of understanding and connection.

Interviews examined participants' backgrounds and beliefs, perceptions of the project, learning experiences and pedagogical interests on art and education, perceptions of self, and the community. Questions were developed around the following axes that reach to the very heart of teacher trainees' a/r/tographic journey:

- Are you making art?

- Are you researching?

- Are you educating?

\section{Results}

\subsection{The Artist Self}

Art -making was a fundamental part of the project through which a rich production of artistic expressions was obtained. 120 individual scarecrows varying in size, shape, style, material and representation were produced and grouped according to their thematic depiction, in more than 25 sets presenting typical scenes of traditional life in a rural area.

Regarding their role as artists, teacher trainees contributed to

- the construction of individual artworks (scarecrows)

- the formation of rural scenes and 
- the complete ephemeral artistic intervention in situ, where the scenes of scarecrows decorated the entire village.

The last act, a local festival, was the major artistic 'product' of the project. More than 200 scarecrows became the complete scenery for the implementation of a full-day program of non-traditional activities. There were scarecrows representing bakers, fishermen, woodcutters, farmers, breeders, weavers, housewives, doctors of medicine, teachers etc. Among the scenes one could meet a traditional marriage (consisting of scarecrows representing the bride and groom, the best men and the priest), the harvest, a potter's working place, a bakery, a scene of olive picking, a coffee grinding corner, a workshop of loom-weaving etc.

The answers of the participants illuminate their experiences in artistic creations as a process of self discovery. Their artworks allowed representations, understandings and interpretations that can change patterned ways of knowing, seeing, and being in the world.

By giving shape to the scarecrows, the artists translated local cultural heritage into the language of the present and identified the past as source of inspiration which may eventually influence the future of the region Furthermore the art-making described as 'empowering and liberating' expanded their opinion about the social nature of knowledge as public interaction

\subsection{The Teacher Self}

Throughout the project teachers revealed themselves as researchers as well as those researched. Regarding their role as researchers, teacher trainees contributed in various phases of the inquiry, mainly in the data collection phase.

It must be noted that the overall project was assessed using multiple quantitative and qualitative approaches. The quantitative indices concerned the number of participants, estimated number of visitors, number of products (scarecrows and sets) and the qualitative results concerned the degree of satisfaction and usefulness as derived from interviewing a sample of participants. By collecting, recording and organizing information from the project's results, evaluation succeeded to respond to demands for accountability, assess effectiveness and efficiency in the use of resources, recognize actual changes and progress made, identify factors of success and needs for improvement and reveal whether desired outcomes are being achieved.

Regarding their role as those researched, their engagement in artistic expressions was first assessed through an analysis of individual scarecrows, sets of scarecrows and overall final artistic synthesis, applying creativity criteria of flexibility and transformation (Zimmerman, 1992). This assessment concerned all groups of participants (pupils, university students and adults).

Second, their artistic and educational praxis became an a site for inquiry, served as a 'window that enables us to understand their attitudes on the subjects examined' (Scherz, \& Oren, 2006). Here lies the heart of of $\mathrm{a} / \mathrm{r} /$ tography as a living practice 'through which meaning is conceptualized and expressed' (Eisner, 1999).

Being part of the research, teachers' trainees were empowered to create their own personalized representation of their knowledge and perceptions and thus better understand 
bodies of literature within and across fields of art and education.

\subsection{The University Students}

For the University students, participation in the project gave them an opportunity to educate others. Regarding their roles as educators, teacher trainees, along with members of the academic staff:

- Communicated with several schools and representatives of cultural organizations on the island informing about the project and discussing the possibility of cooperation. Those who responded positively formed the school team and the society team.

- Informed the participants about the symbolic meaning of the scarecrow and through it to the importance of nature, land, rural life in the past and present, the gradual transformation in occupations and the gradual changes in the economic, social and cultural features of life.

- Motivated participants to construct scarecrows providing information concerning environmental art and 'arte povera' (Christov-Bakargiev, 1999).

The educational experiences influenced teacher trainees to develop as pedagogues. The words 'teaching',' learning' and 'education' are seeded throughout their descriptions and for two of them engagement with the project was fundamental in changing their understanding about knowledge, attitudes, behaviors and skills required to perform their tasks effectively in the classroom, school and wider community.

Here are some excerpts from the discussions with the teacher trainees:

'So far, I have never adopted a specific style of teaching, but now my previous concept validation of my role as a teacher has changed'.

'At the beginning I did not have the slightest idea of creating a scarecrow... To be honest, I did not have the slightest idea of creating anything artistic!'

'We tried to make the scenes get life by motivating local people engaged in traditional occupations to participate in the scenes... it was as artworks came to life '

'The response of habitats was impressive! Thus near the scene of olive picking, olive oil producers were selling their products.

'It was just a bunch of wasted material and then...I couldn't believe it!!!”

'The production of complete scenes of rural life, made me realize the dynamics of the project'

'I spoke to the students about the importance of transforming waste materials of no-cost in creative constructions and of applying simple art instruments and techniques so as to give a personal character to their creations'.

'While creating, I was thinking to enrich my artwork with qualities that connected past and present '. 
'In regard to materials, I had used dozens of different materials to construct heads, arms, clothes..'

'Being researcher and on one of those researched, helped me to gain new knowledge'

'We were given some basic instructions about the construction process and were encouraged to draw first and then to construct their free expressions of scarecrows.'

'It is all about transformative learning!'

'I collected data, from visitors about the targets of the project and then I became the object of the study!'

'Patchwork, painting and collage...Those were the techniques we used to decorate scarecrows'

'The next mission was to use the scarecrows, grouped according to their thematic depiction, in order to form rural sets and scenes.'

'We inform the participants about the symbolic meaning of the scarecrow and through it to the importance of nature, land, rural life in the past and present, the gradual transformation in occupations and the gradual changes in the economic, social and cultural features of life '

'Together with habitats we located spots in the settlement appropriated for hosting the scenes. The combination of artistic products with authentic objects was very successful resulted in interesting artistic interventions'

'All this devoted in the revival of traditions and local culture was so innovative ...and most important it made me understand the artist in myself!!'.

'I was both placing myself in the role of the researcher and subject of research. I must admit that the first was a much easier task!

'Learners should play a more active role...the role of the teacher is to help students build up their knowledge'.

'I imagine myself teaching art within public spaces...'

\section{Conclusions}

The aim of the study was an a/r/t/ographical approach of an interdisciplinary educational project where art-making and teaching processes were seen as acts of research. Through the lens of $\mathrm{a} / \mathrm{r} /$ tography with focus on teachers-trainees, the project was seen as a multidimensional inquiry, a holistic teaching strategy and an access to creating, and performing art. Data collected during interviews and informal discussions illuminate the role of art-based educational projects in learning through three deeply interrelated aspects of a/r/tographical self: the artist, the researcher and the teacher self (Prendergast, Leggo, \& Sameshima, 2009). More specifically such a focus highlights:

(a) The blurring of borders between the roles of artist, researcher and teacher. Operating as teachers, artists, researchers as well as those researched, the University students envision a 
condition 'embodied understandings and exchanges between and among the broadly conceived identities of artist/researcher/teacher' (Irwin \& Sinner, 2013: ii).

(b) The social-collaborative nature of artist/researcher/teacher self.

The project led participants to look into the 'openings' created by artistic creations, social activities and shared inquiries and thus think about their own connections to community (Irwin \& Sinner, 2013).

(c) The potential of $\mathrm{a} / \mathrm{r} /$ tography play in re-conceptualizing teacher education.

The results of this study raise questions about teaching teachers how to teach. Having participated in a project that: made them realize:

- the complexities of educating and being educated

- the kind of education they want to be involved in

- the connections between theory and in practice,

teacher trainees seek learners-centric, multi-dimensional interdisciplinary educational projects that promote teaching as social practice.

(d) The process of learning.

Being researchers and artists, students and educators, University students were immersed in a journey of discovery and co-construction of knowledge concerning

- Teaching and Education.

- Values of art, sustainability, cooperation and active participation in environmental, social, developmental and cultural activities.

- Cognitive, communicative and artistic skills

- Respect for natural, economic, social and cultural environment

- Respect for cultural heritage

- Empowering people so as to determine their own cultural social and economic future, linking it to their past and present.

Learning which results from the $\mathrm{a} / \mathrm{r} /$ tographic research process can be understood as 'significant' (Fink, 2003). According to Fink (2003), significant learning takes place when meaningful and lasting experiences occur during the educational process. Gaining skills, and insights that learners see as meaningful and salient to them promote engagement in the learning process and greater learning occurs.

As agents in their own learning, a/r/tographers can begin to create more nurturing teaching and learning spaces for both self and the students entrusted to them (Mantas \& Di Rezze, 2011). 


\section{References}

Adler, N. (2004). The Arts and Leadership: Now That We Can Do Anything, What Will We Do? Academy of Management Journal of Learning \& Education, 5(4).

Armstrong, T. (2000). Multiple intelligences in the classroom. Alexandria, VA: Association for Supervision and Curriculum Development.

Austin, R., \& Devin, L. (2003). Why Managing Innovation is Like Theater: Working Knowledge. Harvard Business School.

Baum, S., Viens, J., \& Slatin, B. (2005). Multiple intelligences in the classroom: A teacher's guide. New York, NY: Teachers College Press.

Beare, D. (2009). A/r/tography, Secondary Theatre Teaching and The Theatre of Possibilities project. Youth Theatre Journal, 23(2), 162-175.

Bickel, B. (2006). Book Review - A/r/tography: rendering self through arts based living inquiry. Studies in Art Education, 48(1), 118-122.

Bickel, B. (2008). Unveiling a sacred aesthetic: A/r/tography as ritual. In S. Springgay, R. Irwin, C. Leggo, \& P. Gouzouasis (Eds.), Being with a/r/tography (pp. 81-94). Rotterdam, Netherlands: Sense Publishers.

Carmena, H. (2011). Helping Students Relate to Science and Art. Science Blogs. Retrieved from http://scienceblogs.com/art_of_science_learning/2011/03/16/helping-students-relate-tosci-1/

Carter, M., Beare, D., Belliveau, G., \& Irwin, R. L. (2011). A/r/tography as pedagogy: A promise without guarantee. Canadian Review of Art Education: Research and Issues, 38, 17-32.

Catterall, J. S., \& Deasy, R. (Eds.) (2002). Critical Links: Learning in the Arts and Student Academic and Social Development. Washington DC: National Endowment for the Arts, The Arts Education Partnership.

Christov-Bakargiev, C. (2005). Arte Povera (Themes \& Movements). Phaidon Press.

De Cosson, A. (2003). (Re) searching sculpted a/r/tography: (Re ) learning subverted-knowing through aporetic praxis. (Unpublished doctoral dissertation. Vancouver: University of British, Columbia).

Deleuze, G., \& Guattari, F. (1987). A Thousand Plateaus. Minneapolis: University of Minnesota Press.

Dewey, J. (1934). Art as experience. New York: Pedigree.

Di Rezze, G., \& Mantas, K. (2006). The art of box-ing in/out: Co-creative process and artful inquiry in women educators' learning. New Zealand Journal of Adult Learning, 34(2), 59-70.

Efland, A. (1990). A History of Art Education. Intellectual and social currents in teaching the 
visual arts. New York:Teachers College Press.

Eisner, E. (Ed.). (1976). The arts, human development and education. Berkeley, CA:McCutchan.

Eisner, E. W. (2002). The arts and the creation of mind. New Haven \& London: Yale University Press.

Eisner, E. W., \& Day, M. D. (Eds.). (2004). Handbook of Research and Policy in Art Education: A Project of the National Art Education Association. Mahwah, N. J.:Lawrence Erlbaum Associates.

Fink, D. L. (2003). Creating Significant Learning Experiences:An Integrated Approach to Designing College Courses. San Francisco:Jossey-Bass.

Gouzouasis, P. (2008). Toccata on assessment, validity \& interpretation. In S. Springgay, R. Irwin, C. Leggo, \& P. Gouzouasis (Eds.), Being with a/r/tography (pp. 221-232). Rotterdam, the Netherlands: Sense.

Gradle, S. (2007). Spiritual ecology in art education: A re-vision of meaning. In L. Bresler (Ed.), International handbook of research in arts education (pp.1501-1516). New York, NY: Springer.

Gruenewald, D. A. (2003). The best of both worlds: A critical pedagogy of place. Educational Researcher, 32, 3-12.

Gude, O. (2009). Art Education for Democratic, Life. Lowenfeld Lecture. National Art Education Association. Minnesota, Minneapolis.

Hadzigeorgiou, Y. (2005). Romantic understanding and science education. Teaching Education, 16, 23-32.

Irwin, R. L. (2003). Towards an aesthetic of un folding in/sights through curriculum. Journal of the Canadian Association for Curriculum Studies, 1(2), 63-78.

Irwin, R. L. (2004). A/r/tography: A metonymic métissage. In R. L. Irwin \& Alex de Cosson (Eds.), A/r/tography: Rendering self through arts - based living inquiry (pp. 27-40). Vancouver, BC: Pacific Educational Press.

Irwin, R. L. (2008). Communities of a/r/tographic practice. In S. Springgay, R. Irwin, C. Leggo, \& P. Gouzouasis (Eds.), Being with a/r/tography (pp.71-80). Rotterdam, the Netherlands: Sense

Irwin, R. L. (2013). Becoming A/r/tography. Studies in Art Education, 54(3).

Irwin, R. L., \& de Cosson, A. (Eds.) (2004). A/r/tography: Rendering self through arts based living inquiry. Vancouver: Pacific Educational Press.

Irwin, R. L., \& Springgay, S. (2008). A/r/tography as practice-based research. In S. Kampouropoulou, M., Athanasiadis, I., Stefos, E. (2011). Students' views on the use of New Technologies in Art Education: An interdisciplinary approach to Higher Education. Review of 
European Studies, 3(1), 60-70.

Irwin, R. L., Beer, R., Springgay, S., Grauer, K., Xiong, G., \& Bickel, B. (2006). The hizomatic relations of a/r/tography. Studies in Art Education, 48(1), 70-88.

Kampouropoulou, M., Fokiali, P, \& Hadzigeorgiou, Y. (2011). Students' Views on the Use of New Technologies in Art Education: An Interdisciplinary Approach to Higher Education. Review of European Studies, 3(1), 60-70.

Kampouropoulou, M., Fokiali, P., \& Hatzigeorgiou, Y. (2011). Art Education, Cultural Heritage and Sustainable Community Development: The case of Asklipeio Scarecrows Festival in Rhodes. Paper presented in the 33rd InSEA World Congress, 25 - 30 June, Budapest.

Kampouropoulou, M., Fokiali, P., \& Hatzigeorgiou, Y. (2011). Using a feature film to integrate Art, Science and Economics. 33rd InSEA World Congress, 25 - 30 June 2011 Budapest

Knowles, \& Cole, A. (2008). Handbook of the Arts in Qualitative Research: Perspectives, Methodologies, Examples, and Issues. SAGE Publications

Labriole, M. (2010). Promoting Brain-Science Literacy in the K-12 Classroom. Cerebrum.

Leggo, C. (2008). Autobiography: Researching our lives and living our research. In Springgay, R. Irwin, C. Leggo, \& P. Gouzouasis (Eds.). Being with a/r/tography (pp. 3-24). Rotterdam, the Netherlands: Sense.

Macdonald, S. (2004). The History and Philosophy of Art Education. The Lutterworth Press.

Mantas, K., \& Di Rezze, G. (2011) On becoming 'wide-awake’: A creative process as teacher development. Artful re-search and co-creative process as teacher development. International Journal of Education and the Arts, 12(4).

Noddings, N. (1992). The challenge to care in schools: An alternative approach to education. New York, NY: Teachers College Press.

Noddings, N. (Ed.). (2005). Educating citizens for global awareness. New York, NY: Teachers College Press.

Norman, R. (2008). The art of poetry and narrative with and between lived curriculum: Autobiographic a/r/tography. In S. Springgay, R. Irwin, C. Leggo, \& P. Gouzouasis (Eds.), Being with a/r/tography (pp. 33-44). Rotterdam, the Netherlands: Sense

O'Sullivan, S. (2006). Art encounters Deleuze and Guattari: Thought beyond representation. New York: Palgrave Macmillan.

Pourchier, N. M. (2010). Art as Inquiry: A Book Review of Being with A/r/tography. The Qualitative Report, 15(3), 740-745.

Prendergast, M., Leggo, C., \& Sameshima, P. (Eds.). (2009). Poetic inquiry: Special issue. Educational Insights, 13(3). Last upload: 3/2/2014 from: www.educationalinsights.ca. 
Prendergast, M.. Leggo, C., \& Sameshima, P. (2009). Poetic Inquiry. Sense Publishers.

Root-Bernstein, R. (2008). Art Smarts Among Innovators in Science, Technology, Engineering, and Mathematics (STEM). Michigan State University: University Outreach and Engagement,

Scherz, Z., \& Oren, M. (2006). How to change students' images of science and technology. Science Education, 90(6), 965-985.

Seifter, H., \& Buswick, T. (2005). Arts-Based Learning for Business. Emerald Group Publishing

Seifter, H., \& T. Buswick, (Eds.) (2010). Creatively intelligent companies and leaders: Arts-based learning for business. Special issue of Journal of Business Strategy, 31(4).

Sinner, A., Leggo, C., Irwin, R. L., Gouzouasis, P., \& Grauer, K. (2006). Arts-based Educational Research Dissertations: Reviewing the practices of new scholars. Canadian Journal of Education, 29(4), 1223-1270.

Skoumios, M., \& Savvaidou-Kambouropoulou, M. (2012). Investigating Pupils' Images of Science Teaching Using Drawings. The International Journal of Science in Society, 3(2), 179-192.

Springgay, R., Irwin, C. L., \& Gouzouasis, P. (Eds.) (2008). Being with a/r/tography. Rotterdam, the Netherlands: Sense.

Springgay, S. (2001). Joining inner outer spaces lives: Artistic ways of knowing. Paper presented at British Columbia Art Teachers Association Conference, Kelowna, BC.

Springgay, S. (2008). An ethics of embodiment. In S. Springgay, R. Irwin, C. Leggo, \& P. Gouzouasis (Eds.), Being with a/r/tography (pp. 153-166). Rotterdam, the Netherlands: Sense.

Springgay, S., Irwin Rita, L., \& de Cosson, A. (2008). The liminal(s) phaces of a/r/tographical research. In Four Arrows, aka D. T. Jacobs (Ed.). The Authentic dissertation: Alternative ways of knowing, research and representation (pp. 241-249). New York, NY: Routledge

Springgay, S., Irwin, R. L., \& Kind, S. (2007). A/R/Tographers and living inquiry. In J. G. Knowles, \& A. L. Cole (Eds.), Handbooks of the arts in qualitative research (pp. 83-92), Toronto, ON: SAGE

Springgay, S., Irwin, R., Leggo, C., \& Gouzouasis, P. (Eds.). (2008). Being witha/r/tography. Rotterdam, the Netherlands: Sense.

Springgay, S., Irwin, R., Wilson Kind, S. \& Darts, D. (2004). A/r/tography: Arts based educational research. Paper presented at National Art Education Association Conference, Denver, CO.

Suominen-Guyas, A. (2008). Water: Moving stillness. In S. Springgay, R. Irwin, C. Leggo, \& P. Gouzouasis (Eds.), Being with a/r/tography (pp. 25-32). Rotterdam, the Netherlands: 
Sense.

Triggs, V., \& Irwin, R. L. (2011). Following a/r/tography in practice: From possibility to potential. In K. Miraglia \& C. Smila (Eds.), Inquiry in action: Research methodologies in art education. VA: National Art Education Association

Ulbricht, J. (1998). Changing concepts of environmental art education: Towards a broader definition. Art Education, 51(6), 22-34.

Vallance, E. (1977). The landscape of the"Great Plains Experience": An application of curriculum criticism. Curriculum Inquiry, 7(2), 87-105.

Wilson, B. (2003). Of diagrams and rhizomes: Visual culture, contemporary art, and the impossibility of mapping the content of art education. Studies in Art Education, 44(3), 214-299.

Winters, K.-L., Belliveau, G. \& Sherritt, L. (2009). Shifting identities, literacy, and a/r/t/ography: Exploring an educational theatre company. Language and Literacy, 11(1). Retrieved from from: http://www.langandlit.ualberta.ca/

Wong, D., Pugh, K., and the Dewey Ideas Group at Michigan State University. (2001). Learning science: A Deweyan perspective. Journal of Research in Science Teaching, 38, 317-336.

Zimmerman, E. (Ed.) (2010). Reconsidering the role of creativity in art education [Special Issue]. Art Education, 63(2).

\section{Copyright Disclaimer}

Copyright reserved by the author(s).

This article is an open-access article distributed under the terms and conditions of the Creative Commons Attribution license (http://creativecommons.org/licenses/by/3.0/). 